\title{
Ultrastructural and Cytochemical Aspects of Silicon-Mediated Rice Blast Resistance
}

\author{
Fabrício Á. Rodrigues, Nicole Benhamou, Lawrence E. Datnoff, Jeffrey B. Jones, and Richard R. Bélanger
}

First and fourth authors: University of Florida-IFAS, Department of Plant Pathology, Gainesville 32611; second author: Département de Phytologie, Recherche en Sciences de la Vie et de la Santé, Pavillon C. E. Marchand, Université Laval, Sainte-Foy, Québec, Canada, G1K 7P4; third author: University of Florida-IFAS, Department of Plant Pathology, Everglades Research \& Education Center, 3200 E. Palm Beach Rd., Belle Glade 33430; and fifth author: Centre de Recherche en Horticulture, Département de Phytologie, Université Laval, Sainte-Foy, Québec, Canada, G1K 7P4.

Accepted for publication 9 December 2002.

\begin{abstract}
Rodrigues, F. Á., Benhamou, N., Datnoff, L. E., Jones, J. B., and Bélanger, R. R. 2003. Ultrastructural and cytochemical aspects of silicon-mediated rice blast resistance. Phytopathology 93:535-546.

Although exogenous application of silicon ( $\mathrm{Si}$ ) confers efficient control of rice blast, the probable hypothesis underlying this phenomenon has been confined to that of a mechanical barrier resulting from $\mathrm{Si}$ polymerization in planta. However, in this study, we provide the first cytological evidence that $\mathrm{Si}$-mediated resistance to Magnaporthe grisea in rice correlates with specific leaf cell reaction that interfered with the development of the fungus. Accumulation of an amorphous material that stained densely with toluidine blue and reacted positively to osmium tetroxide was a typical feature of cell reaction to infection by $M$. grisea in samples from $\mathrm{Si}+$ plants. As a result, the extent of fungal colonization

was markedly reduced in samples from $\mathrm{Si}+$ plants. In samples from $\mathrm{Si}-$ plants, $M$. grisea grew actively and colonized all leaf tissues. Cytochemical labeling of chitin revealed no difference in the pattern of chitin localization over fungal cell walls of either $\mathrm{Si}+$ or $\mathrm{Si}-$ plants at $96 \mathrm{~h}$ after inoculation, indicating limited production of chitinases by the rice plant as a mechanism of defense response. On the other hand, the occurrence of empty fungal hyphae, surrounded or trapped in amorphous material, in samples from $\mathrm{Si}+$ plants suggests that phenolic-like compounds or phytoalexins played a primary role in rice defense response against infection by $M$. grisea. This finding brings new insights into the complex role played by $\mathrm{Si}$ in the nature of rice blast resistance.

Additional keywords: gold cytochemistry, host-pathogen interaction, Oryza sativa.
\end{abstract}

Rice blast, caused by the fungus Magnaporthe grisea (T.T. Hebert) Yaegashi \& Udagawa) Barr (anamorph Pyricularia grisea (Cooke) Sacc.), is the most important constraint to rice (Oryza sativa L.) production worldwide (27). Infection of rice by $M$. grisea begins after a conidium lands on the adaxial epidermis. Upon contact with the leaf surface, mucilage is released from the periplasmic space at the tip of the conidium to serve as an adhesive to its attachment (14). Thereafter, a germ tube emerges from the germinating conidium, which grows parallel to the leaf surface until an appressorium is formed (23). Appressorium melanization allows $M$. grisea to penetrate directly through the cuticle and the epidermal cell wall (16). Direct penetration is facilitated by the accumulation of high concentration of glycerol within the appressorium (19). In a following step, an influx of water molecules moves into the appressorium to generate a hydrostatic turgor, which is focused and translated into a mechanical force, allowing a narrow penetration peg to rupture the cuticle. Once inside the epidermal cell, fungal hyphae differentiate from a vesicle produced by the penetration peg and ramify intra- and intercellularly. Although the incubation period of rice blast is affected by temperature and relative humidity, a necrotic lesion becomes visible on the leaf blade around $72 \mathrm{~h}$ after infection. Aerial conidiophores differentiate from within the lesion around 5 to 7 days after infection takes place to produce conidia, which initiate new blast cycles (27).

Corresponding author: L. E. Datnoff; E-mail address: ledatnoff@ifas.ufl.edu

Florida Agricultural Experiment Station Journal Series R-09088.

Publication no. P-2003-0226-01R

(C) 2003 The American Phytopathological Society
An integrated control strategy for implementation in environments with high epidemic potential to blast includes the use of partially resistant cultivars, early sowing and transplanting of seedlings, water and nitrogen management, as well as treatment of seeds or foliar application of fungicides $(5,27)$. Another approach gaining increased interest is the use of silicon $(\mathrm{Si})$. Increased $\mathrm{Si}$ content in rice tissue has been associated with resistance to blast, brown spot (Cochliobolus miyabeanus (Ito \& Kuribayashi in Ito) Drech. ex Dastur), stem rot (Magnaporthe salvinii (Cattaneo) R. Krause \& R.K. Webster), leaf scald (Monographella albescens Theum), sheath blight (Thanatephorus cucumeris (A.B. Frank) Donk), and grain discoloration $(8,29,32)$. In many cases, Si can control rice blast as effectively as recommended fungicides, mainly because it has the potential to increase partial resistance of cultivars to the same general level as complete resistance (9). In this context, $\mathrm{Si}$ amendments can be considered an effective strategy to control blast disease, especially when rice is cultivated in Si-deficient soil.

The mechanism(s) underlying the $\mathrm{Si}$-mediated resistance to rice blast remain, so far, poorly understood and inconclusive. From a morphological viewpoint, the increased resistance to blast has been associated with the density of silicified cells in the epidermis $(15,17,38)$. On the other hand, the cuticle-silica double layer formed upon deposition and polymerization of silicic acid beneath the cuticle is another hypothesis commonly accepted for explaining the role of Si-mediated resistance against penetration by $M$. grisea (43). Recently, Kim et al. (21) investigated some of the cytological features of Si-mediated resistance to blast. They observed that the epidermal cell wall thickness was not significantly affected by Si. However, the thickness ratios of silica layers to epidermal cell walls were much higher in the resistant cultivar than in the susceptible one. Although the fortification of epidermal 
cell walls was considered as the main cause for the observed reduced number of leaf blast lesions, evidence that the narrow penetration peg of $M$. grisea did not overcome the physical impedance offered by the fortified cell wall was not provided. Interestingly, Ito and Sakamoto (18) studied the puncture resistance of epidermal cells to a needle tip from beneath a torsion balance using leaves collected from rice plants grown under different Si rates. According to their results, the puncture resistance was not explained solely by the leaf epidermis silicification; rather, it was attributed mainly to the nature of the protoplasm of epidermal cells. In another work, it was reported that rice cultivars resistant to blast had lower lesion numbers and silicified epidermal cells than susceptible ones (20). Therefore, it seems plausible that rice resistance to $M$. grisea colonization is much more complex than a physical resistance by silicified cells. Seebold et al. (33) quantified the effects of $\mathrm{Si}$ on several components of resistance to blast. They provided clear evidence that by increasing $\mathrm{Si}$ rates, the incubation period was lengthened and the number of sporulating lesions, lesion size, rate of lesion expansion, and the number of spores per lesion in rice cv. M-201 were markedly reduced. In cucumber, there is clear evidence that $\mathrm{Si}$ mediates a number of cell defense reactions that confers protection against Pythium ultimum and Sphaerotheca fuliginea $(7,25)$. Zeyen et al. (44) demonstrated that soluble $\mathrm{Si}$ was present in considerable amounts during and immediately following papilla deposition in barley epidermal cells infected by Erysiphe graminis. They suggested that Si may play a physiological or a biochemical role during attempted fungal penetration. However, in the rice- $M$. grisea interaction, to our knowledge, no studies to date have investigated whether Si could influence the physiology of the cell response to $M$. grisea infection.

The objectives of this work were to investigate the outcome of the rice- $M$. grisea interaction on Si treatment and to determine ultrastructurally if any cytological or biochemical changes were associated with fungal restriction in planta. A portion of this study was previously reported (28).

\section{MATERIALS AND METHODS}

Experiments were conducted under greenhouse conditions at the University of Florida, Gainesville, and the electron microscope study was conducted at the Pavillon C. E. Marchand, Université Laval, Québec, Canada.

Rice plant growth and $M$. grisea inoculation. Rice cv. M-201 (CI 9980) was chosen in this study because it has no reported major or minor resistance gene to race IB-49 of M. grisea (33). Plastic pots, $12 \mathrm{~cm}$ in diameter, were filled with $2 \mathrm{~kg}$ of peat Fafard No. 2 (Conrad Fafard Inc., Agawan, MA) and amended with calcium silicate slag (22\% available soluble $\mathrm{Si}$ ) (Calcium Silicate Corp.; Lake Harbor, FL) at the rates of 0 and $20 \mathrm{~g} \mathrm{pot}^{-1}$ (20 t/ha) 4 days before sowing. Silicon concentration in the substrate was $4 \mathrm{mg}$ of Si liter ${ }^{-1}$. Seeds were sown at the rate of eight seeds per pot, and at 3 days after emergence, each pot was thinned to two seedlings. Seedlings were then fertilized after thinning by adding $100 \mathrm{ml}$ of a nutrient solution to each pot containing, in milligrams per kilogram of peat Fafard No. 2, $100 \mathrm{~N}, 300 \mathrm{P}$, $150 \mathrm{~K}, 85 \mathrm{Ca}, 70 \mathrm{Mg}, 40 \mathrm{~S}, 0.81 \mathrm{~B}, 1.33 \mathrm{Cu}, 3.66 \mathrm{Mn}, 0.15 \mathrm{Mo}$, and $4.00 \mathrm{Zn}$ (29). Iron deficiency was avoided by adding $8 \mathrm{ml}$ of a solution containing $300 \mathrm{~g}$ of $\mathrm{FeSO}_{4}$ liter $^{-1}$ per pot. No modifications were made to the pots to allow for drainage, and plants were kept under flooded conditions until the end of the experiments.

Inoculations were made at the time of emergence on the seventh leaf from the main tiller (24). A conidial suspension of race IB-49 of $M$. grisea $\left(4 \times 10^{5}\right.$ conidia $\left.\mathrm{ml}^{-1}\right)$ was applied as a fine mist to the upper leaf blades of two plants per pot until runoff with an aerosol sprayer (Crown Spra-Tool; Fisher Scientific Co., Pittsburgh, PA). Gelatin (1\%, wt/vol) was added to the sterile water to aid conidial adhesion to the leaf blades. Immediately after inocu- lation, plants were covered with a dew plastic bag and transferred to a chamber at $25^{\circ} \mathrm{C}$ under a $12 \mathrm{~h}$ photoperiod of approximately $162 \mu \mathrm{E} \mathrm{m} \mathrm{m}^{-2} \mathrm{~s}^{-1}$ provided by cool-white fluorescent lamps, starting with an initial $24 \mathrm{~h}$ dark period. Pots were placed in trays of water that maintained the relative humidity at approximately $85 \%$ throughout the experiments. After $48 \mathrm{~h}$, plastic bags were removed and plants were kept in the chamber for the duration of the experiments.

Sampling of treatments and evaluation of blast lesion development. Because rice susceptibility to $M$. grisea is affected by leaf age (27), samples were collected from the fourth, fifth, and sixth leaves to insure the use of leaves of the same age among treatments. A total of 25 to 30 leaf pieces, approximately $30 \mathrm{~mm}^{2}$ in size and containing individual infection sites, were randomly collected from those leaves on each of two plants per treatment at $48,72,96$, and $120 \mathrm{~h}$ after inoculation with $M$. grisea. Representative leaves from each treatment were photographed with a digital camera at each sampling time to record the pattern of blast lesion development. The experiment was repeated twice and each treatment consisted of three replicates.

Processing of leaf sample for light and transmission electron microscopy. Leaf samples were transferred to glass vials, fixed with $10 \mathrm{ml}$ of a solution composed of $3 \%$ ( $\mathrm{vol} / \mathrm{vol}$ ) glutaraldehyde and $2 \%$ paraformaldehyde ( $\mathrm{vol} / \mathrm{vol})$ in $0.1 \mathrm{M}$ sodium cacodylate

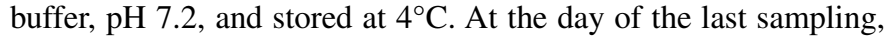
leaf samples from all treatments were carefully washed with sodium cacodylate buffer and postfixed with $1 \%$ (wt/vol) osmium tetroxide prepared in the same buffer for $40 \mathrm{~min}$ at room temperature. Samples were then dehydrated in a graded ethanol series and embedded in Jembed 812 resin (Canemco Inc., Québec, Canada) in flat embedding molds. Thick sections $(0.5$ to $0.7 \mu \mathrm{m})$ were cut from the embedded material with glass knives and stained for $5 \mathrm{~min}$ with $1 \%(\mathrm{wt} / \mathrm{vol})$ toluidine blue $\mathrm{O}$ in $2 \%$ (wt/vol) sodium borate for light microscope observations. Once infection threads were located under the light microscope, ultrathin sections $(0.1 \mu \mathrm{m})$ were obtained from the embedded material with a diamond knife. Ultrathin sections were mounted on nickel grids, stained with $2 \%$ uranyl acetate for $10 \mathrm{~min}$ followed by $5 \mathrm{~min}$ in $1 \%$ lead acetate, and examined by transmission electron microscopy (TEM) (JEOL 1200 EX; JEOL Ltd., Tokyo) operating at 80 kV. For each experiment, five to eight blocks per treatment were carefully selected for cuttings. From each block, six thick and four to six ultrathin sections were examined under the light and electron microscope, respectively.

Cytochemical labeling and controls. Gold particles, averaging 12 to $15 \mathrm{~nm}$ in diameter, were prepared using sodium citrate as a reducing agent according to the method of Frens (13). Wheat germ agglutinin (WGA), a lectin with $\mathrm{N}$-acetylglucosamine-binding specificity, was used in a two-step labeling procedure to localize $N$-acetylglucosamine residues (chitin) according to the method described by Benhamou (1). Because of its low molecular weight, the lectin could not be directly complexed to colloidal gold. An ovomucoid-gold conjugate ( $\mathrm{pH}$ 5.4) was used as a second-step reagent. For the localization of cellulosic $\beta$-1,4-glucans, an exoglucanase ( $\beta$-1,4-D-glucan cellobiohydrolase, EC 3.2.1.21), purified from a cellulase produced by Trichoderma harzianum, was complexed to colloidal gold at $\mathrm{pH} 9.0$ and used in a one-step procedure as described previously (4). The specificities of the two cytochemical probes used were established by control tests as reported by Benhamou and Brodeur (3). After cytochemical labeling for cellulose and chitin, grids were stained with $2 \%$ uranyl acetate for $10 \mathrm{~min}$ followed by $5 \mathrm{~min}$ in $1 \%$ lead citrate and examined by TEM.

\section{RESULTS}

Development of leaf blast lesions. The pattern of blast lesion development on the adaxial epidermis of leaves from rice cv. 
M-201 grown without and with $\mathrm{Si}$ application is illustrated in Figure 1 . At an early stage of infection ( $48 \mathrm{~h}$ after inoculation), small, brown necrotic specks were visible on inoculated leaves from $\mathrm{Si}-$ and $\mathrm{Si}+$ plants. However, the frequency and size of these necrotic specks appeared greater on leaves from $\mathrm{Si}-$ plants. By $72 \mathrm{~h}$ after inoculation by $M$. grisea, necrotic specks increased on leaves from $\mathrm{Si}+$ plants but were never larger than those from $\mathrm{Si}-$ plants. Many lesions coalesced and the infected area showed early symptoms of chlorosis on leaves from $\mathrm{Si}-$ plants. By $96 \mathrm{~h}$ after inoculation by $M$. grisea, many narrow to slightly elliptical lesions with necrotic centers and brown margins occurred on leaves from $\mathrm{Si}$ - plants compared with a few discrete lesions, with or without a chlorotic halo, on leaves from $\mathrm{Si}+$ plants. At an advanced stage of infection (120 h after inoculation), numerous large and expanding lesions, with white-gray necrotic centers and very well delimited brown margins, were visible on leaves from $\mathrm{Si}-$ plants. Lesions that formed on leaves from $\mathrm{Si}+$ plants were smaller, round to somewhat elongated, and with a restricted necrotic center often surrounded by a very well-developed chlorotic halo.

Light microscope observations. Examination of several thick sections at the light microscope level from two experiments conducted over $120 \mathrm{~h}$ confirmed the visual difference observed in the pattern of lesions that developed on leaves from $\mathrm{Si}-$ and $\mathrm{Si}+$ rice plants. By $48 \mathrm{~h}$ after inoculation, fungal hyphae were restricted to the upper epidermal cells in samples from both $\mathrm{Si}$ and $\mathrm{Si}+$ plants (Fig. $2 \mathrm{~A}$ and $\mathrm{B}$, arrows). A close examination of samples from $\mathrm{Si}+$ plants revealed that fungal hyphae were surrounded by an amorphous material that stained green with toluidine blue (Fig. 2B, arrowheads), indicating the presence of phenolic materials (25). Interestingly, this material also accumulated in the uncolonized mesophyll (Fig. 2B, double arrows). In samples from $\mathrm{Si}-$ plants, fungal hyphae colonized the upper epidermis, the mesophyll, the vascular bundle, and even reached the lower epidermis by $72 \mathrm{~h}$ after inoculation (Fig. 2C). At this stage of colonization, mesophyll cells started to become necrotic. In samples from $\mathrm{Si}+$ plants, fungal hyphae colonized mainly the epidermal cells and were frequently encased by an amorphous material that stained densely with toluidine blue (Fig. 2D, arrowheads). Bulliform cell walls displayed an intense staining with toluidine blue (Fig. 2E, arrowheads), but fungal hyphae present in those cells were not surrounded by this amorphous material at this stage of infection (Fig. 2E, arrows). By $96 \mathrm{~h}$ after inoculation, fungal colonization was widespread in samples from $\mathrm{Si}$ - plants, with extensive damage in the epidermis and the mesophyll (Fig. 2F). Accumulation of an amorphous material was seldom observed in mesophyll cells colonized by $M$. grisea (Fig. 2G, arrowheads). In samples from $\mathrm{Si}+$ plants at $96 \mathrm{~h}$ after inoculation by $M$. grisea, fungal hyphae present in the epidermis and vascular bundle (Fig. 3A, arrowheads) as well as in the bulliform cells and mesophyll cells (Fig. 3B, arrowheads) were surrounded by amorphous material that stained densely with toluidine blue and appeared often as empty shells. At an advanced stage of infection (120 h after inoculation), fungal hyphae were present in all leaf tissues of samples from $\mathrm{Si}$ - plants (Fig. 3C). Host cell walls in the mesophyll were no longer discernible and deposition of an amorphous material occurred scarcely and randomly around fungal cells in the heavily colonized vascular bun-

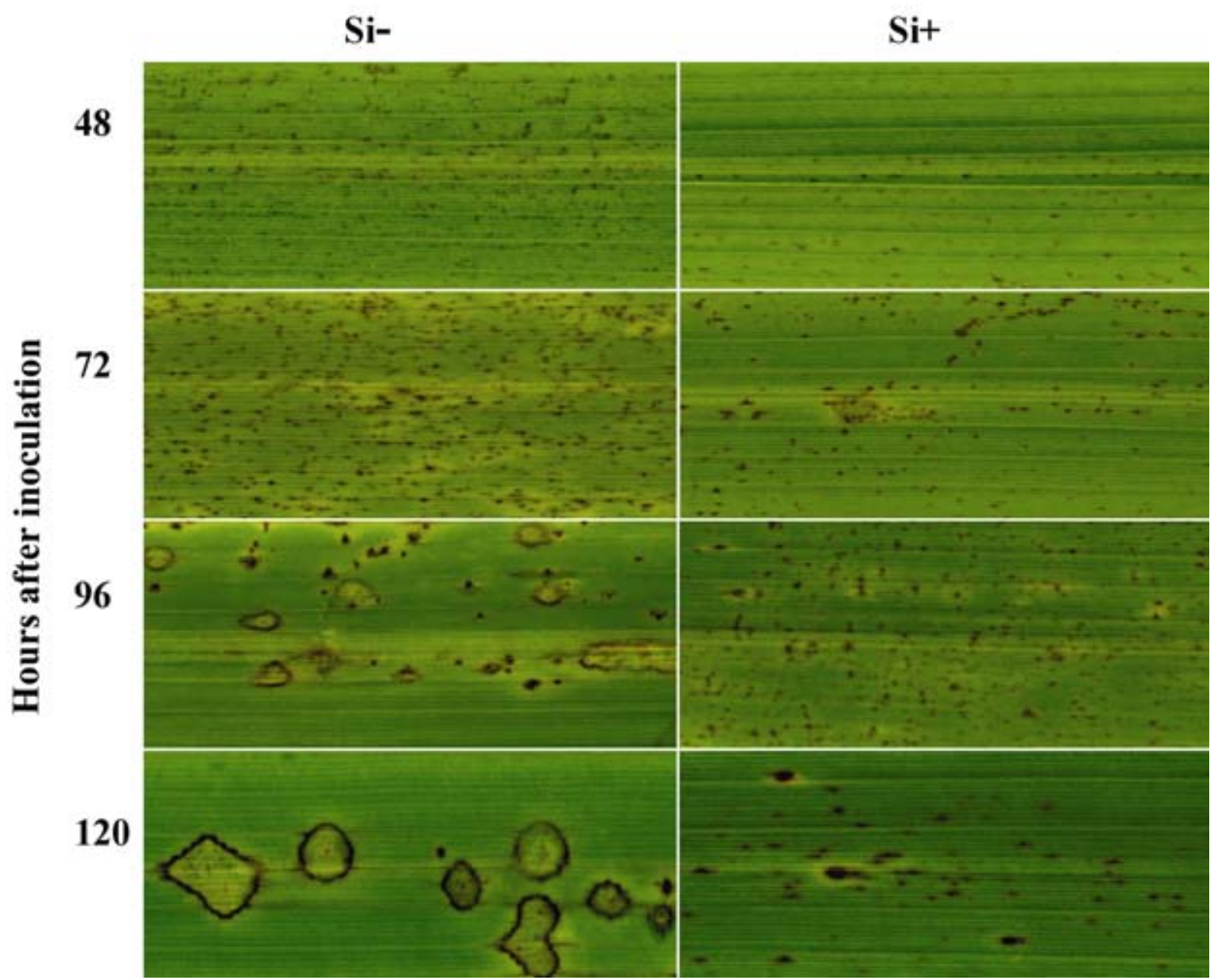

Fig. 1. Development of blast lesions on the adaxial leaf blades of rice plants nonamended ( $\mathrm{Si}-$ ) or amended with silicon ( $\mathrm{Si}+)$ at $48,72,96$, and $120 \mathrm{~h}$ after inoculation with Magnaporthe grisea. 

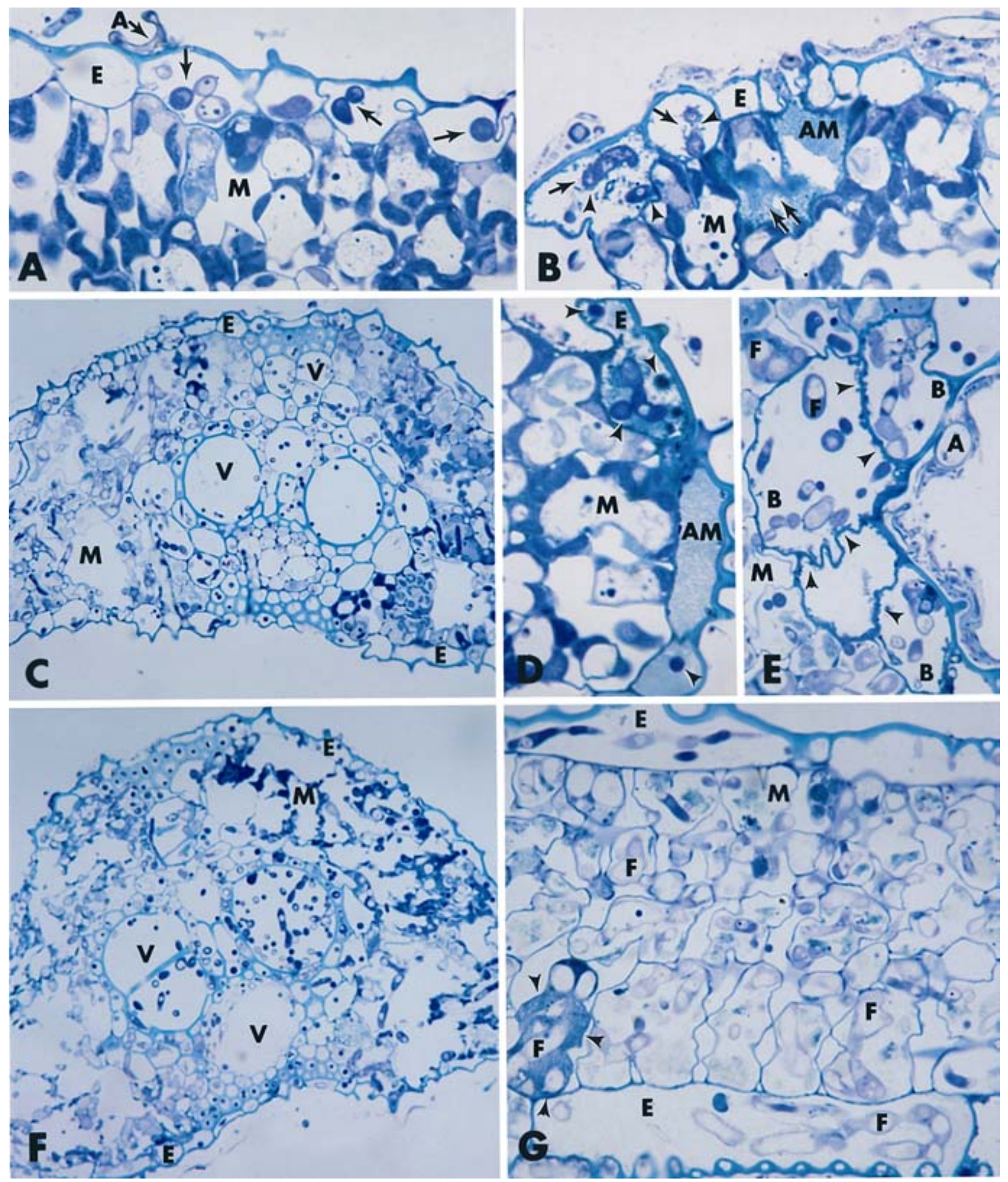

Fig. 2. Light micrographs of leaf samples infected by Magnaporthe grisea and collected in over time experiments from $\mathrm{Si}-$ and $\mathrm{Si}+$ rice plants. Thick resinembedded sections $(0.5$ to $0.7 \mu \mathrm{m})$ were stained with $1 \%$ toluidine blue $\mathrm{O}$ in $2 \%$ sodium borate. A, Fungal hyphae are restricted to the upper epidermal cells (48 h after inoculation; Si-; $\times 1,000$; arrows). An appressorium is formed over an infected epidermal cell. B, Epidermal cells react to $M$. grisea invasion by accumulating an amorphous material that stains green with toluidine blue (arrowheads) and indicates the presence of phenolic-like compounds. This material accumulates also in the mesophyll (double arrows) without fungal invasion (48 $\mathrm{h}$ after inoculation; $\mathrm{Si}+; \times 1,000)$. C, Hyphae of $M$. grisea colonize the upper epidermis, the mesophyll, the vascular bundle, and even reached the lower epidermis. The mesophyll shows signs of disorganized cell walls (72 $\mathrm{h}$ after inoculation; Si-; ×400). D, Fungal hyphae in epidermal cells are surrounded or trapped in the amorphous material ( $72 \mathrm{~h} \mathrm{after} \mathrm{inoculation;} \mathrm{Si}+; \times 1,000$; arrowheads). E, Amorphous material evenly coats the bulliform cell walls (arrowheads). Fungal hyphae are not surrounded by this material (72 $\mathrm{h}$ after inoculation; Si+; $\times 1,000)$. F, Fungal hyphae multiply abundantly in the epidermis, mesophyll, and vascular bundle. Fungal growth in the mesophyll coincides with extensive necrosis ( $96 \mathrm{~h}$ after inoculation; Si-; $\times 400)$. G, Fungal hyphae in the mesophyll are rarely surrounded by the amorphous material (96 h after inoculation; $\mathrm{Si}-; \times 1,000$; arrowheads). Appressorium (A), amorphous material (AM), fungal hyphae (F), epidermis (E), mesophyll (M), bulliform cell (B), and vascular bundle $(\mathrm{V})$. 
dle (Fig. 3C, arrowheads). By contrast, in samples from Si+ plants, a similar pattern of leaf tissue colonization was observed at the same time of infection. However, numerous fungal cells were surrounded or trapped in the amorphous material and often reduced to empty shells in both the mesophyll and the vascular bundle (Fig. 3D, arrowheads). In an attempt to gain further insight into this finding, a more precise investigation at the TEM level was performed.

Transmission electron microscope observations. Examination of ultrathin sections of samples collected from $\mathrm{Si}-$ and $\mathrm{Si}+$ plants confirmed light microscope observations and revealed additional ultrastructural details. By $72 \mathrm{~h}$ after inoculation by $M$. grisea, the fungus had colonized the epidermis (Fig. 4A), meso- phyll (Fig. 4A and B), and vascular bundle (Fig. 4C) of samples from $\mathrm{Si}$ - plants. Successful fungal ingress was achieved through direct host cell wall penetration with a lack of cell wall distortion and extreme constriction of the fungal walls as it passed through the host cell wall (Fig. 4B, arrows). At this stage of colonization, mesophyll cells showed extensive disorganization characterized mainly by cytoplasm breakdown, including chloroplast degradation and cell wall alterations.

An interesting feature consistently observed in samples from $\mathrm{Si}+$ plants was the accumulation of osmiophilic material in colonized cells of both the epidermis and the mesophyll that showed, initially, a fibrillar texture (Fig. 4D and E). This phenomenon was not observed in samples from $\mathrm{Si}-$ plants at the same time of infection.
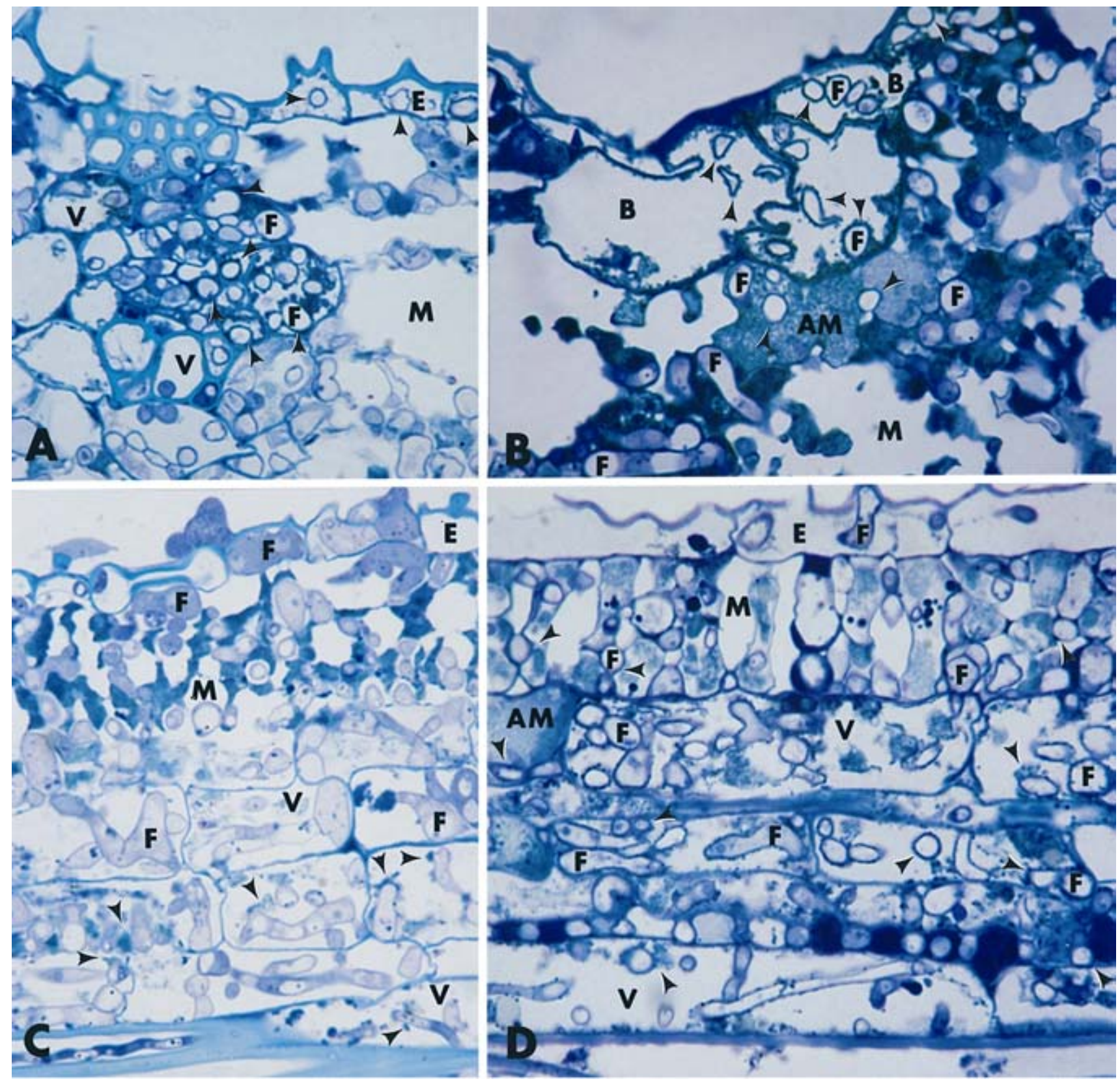

Fig. 3. Light micrographs of leaf samples infected by Magnaporthe grisea and collected in over time experiments from $\mathrm{Si}-$ and $\mathrm{Si}+$ rice plants. Thick resinembedded sections ( 0.5 to $0.7 \mu \mathrm{m})$ were stained with $1 \%$ toluidine blue $\mathrm{O}$ in $2 \%$ sodium borate. A and B, Fungal hyphae colonizing the epidermis, the vascular bundle, the bulliform cells, and the mesophyll are heavily surrounded by amorphous material and appear as empty shells $(96 \mathrm{~h}$ after inoculation; $\mathrm{Si}+; \times 1,000$; arrowheads). C, Fungal hyphae massively colonize the epidermis, the mesophyll, and the vascular bundle. Note the complete dissolution of cell walls in the mesophyll. Hyphae are found outside the epidermis at this time to initiate sporulation. The amorphous material is scarcely deposited around fungal hyphae invading the vascular bundle (120 h after inoculation; Si-; $\times 1,000)$. D, A few fungal hyphae colonize the epidermis and the mesophyll. Fungal hyphae in the vascular bundle are heavily surrounded by dense amorphous material and often reduced to empty shells (arrowheads). Many mesophyll cells do not show sign of strong contraction in response to fungal invasion (120 h after inoculation; Si+; ×1,000). Amorphous material (AM), fungal hyphae (F), epidermis (E), mesophyll (M), bulliform cell (B), and vascular bundle (V). 


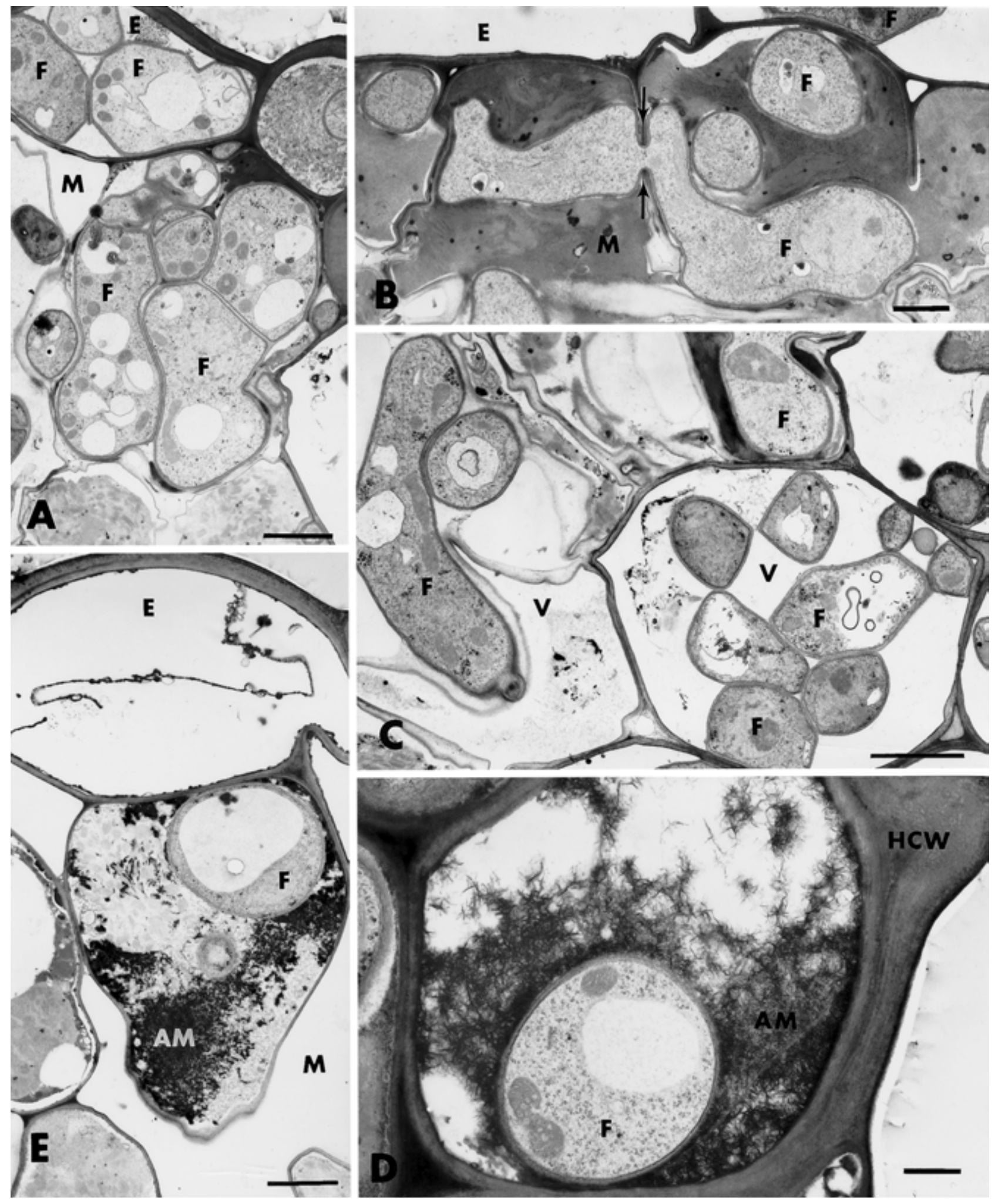

Fig. 4. Transmission electron micrographs of leaf samples collected from $\mathrm{Si}-$ and $\mathrm{Si}+$ rice plants $72 \mathrm{~h}$ after inoculation with Magnaporthe grisea. A, Fungal hyphae massively colonize the epidermis and the mesophyll. The mesophyll cell is completely disorganized and the host cell wall shows signs of marked alteration ( $\mathrm{Si}-$ ). Bar $=2 \mu \mathrm{m}$. B, Fungal hyphae of M. grisea penetrating the cell wall between two mesophyll cells devoid of organized cytoplasm. Note the lack of distortion of the host cell wall at the point of penetration and extreme constriction of the fungal walls as it passes through the cell wall $(\mathrm{Si}-;$ arrows $)$. Bar $=$ $1 \mu \mathrm{m}$. C, Fungal hyphae abundantly colonize the vascular bundle ( $\mathrm{Si}-$ ). Bar $=2 \mu \mathrm{m}$. D, Fungal hyphae that display a normal appearance colonize an epidermal cell almost occluded with an amorphous and fibrillar material $(\mathrm{Si}+)$. Bar $=0.5 \mu \mathrm{m}$. E, Abundant amorphous material is noticed in a mesophyll cell being colonized by the fungus $(\mathrm{Si}+)$. Bar $=2 \mu \mathrm{m}$. Amorphous material (AM), fungal hyphae (F), epidermis (E), mesophyll (M), host cell wall (HCW), and vascular bundle (V). 

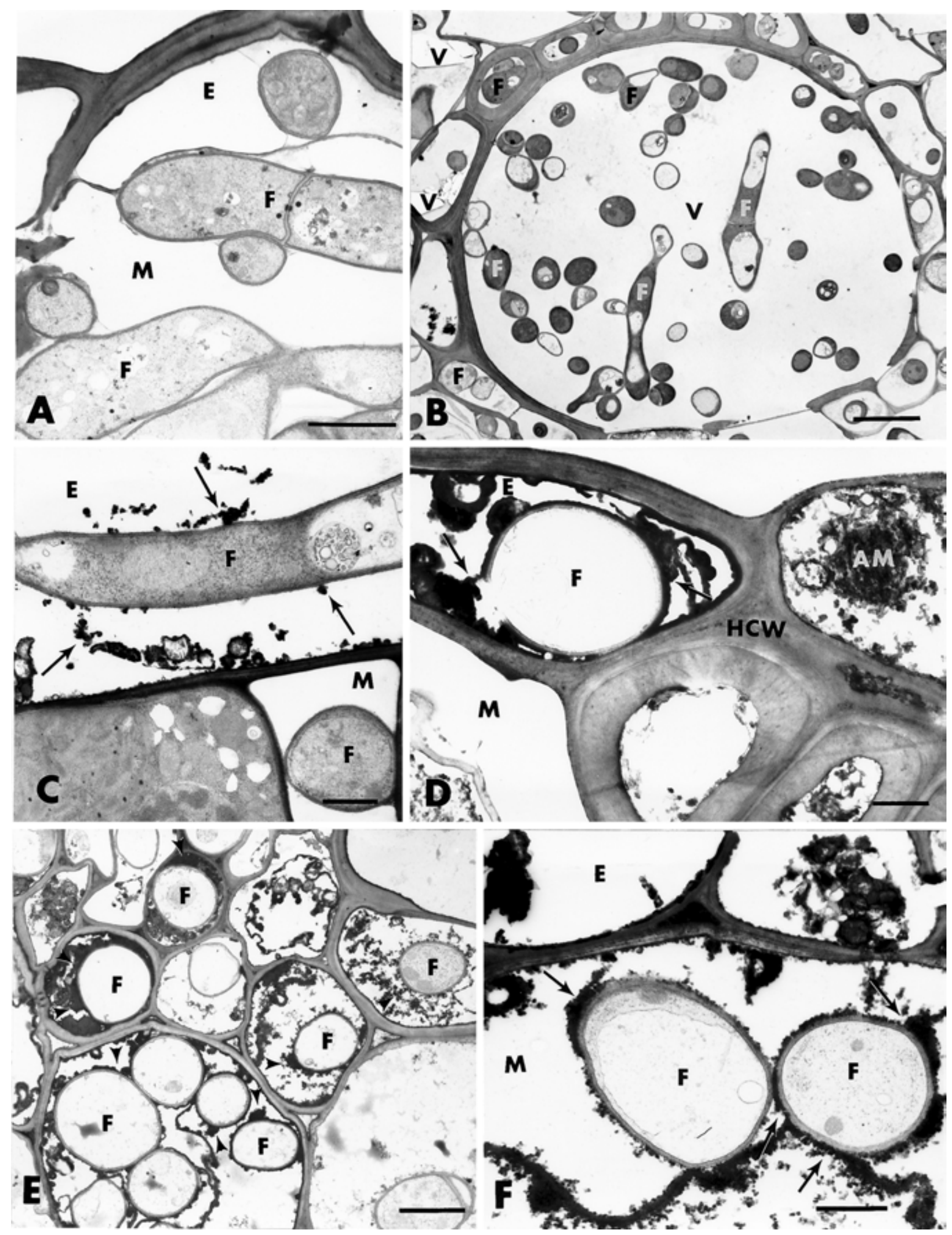

Fig. 5. Transmission electron micrographs of leaf samples collected from $\mathrm{Si}-$ and $\mathrm{Si}+$ rice plants $96 \mathrm{~h}$ after inoculation with Magnaporthe grisea. A, Ultrastructurally normal fungal hyphae colonize both the epidermis and mesophyll. Host cell walls are no longer discernible in the mesophyll $(\mathrm{Si}-)$. Bar $=2 \mu \mathrm{m}$. $\mathbf{B}$, The vascular bundle is massively colonized by the fungal hyphae ( $\mathrm{Si}-$ ). Bar $=5 \mu \mathrm{m}$. C, Some amorphous material (arrows) accumulates in an epidermal cell and irregularly interacts with a fungal cell wall $(\mathrm{Si}-)$. Bar $=1 \mu \mathrm{m}$. D, A dense amorphous material (arrows) accumulates around an empty fungal hyphae in the epidermal cell and also is found in an epidermal cell neighboring the colonized one ( $\mathrm{Si+}+$ ). Bar $=1 \mu \mathrm{m}$. E, Fungal hyphae invading the vascular bundle are often surrounded by dense amorphous material and often reduced to empty shells $(\mathrm{Si}+$; arrowheads). Bar $=2 \mu \mathrm{m}$. F, Two fungal hyphae in a mesophyll cell are evenly coated by the amorphous material ( $\mathrm{Si}+$; arrows). $\mathrm{Bar}=1 \mu \mathrm{m}$. Amorphous material (AM), fungal hyphae (F), epidermis (E), mesophyll (M), host cell wall (HCW), and vascular bundle (V). 
A close examination of samples collected from $\mathrm{Si}-$ plants at $96 \mathrm{~h}$ after inoculation revealed that some host cells were devoid of organelles and that some host cell walls were no longer discernible in the massively colonized mesophyll (Fig. 5A). The vascular bundle was also heavily colonized by $M$. grisea (Fig. 5B). A light deposition of osmiophilic material with a granular texture, occasionally interacting with fungal walls, was seen in some epidermal cells (Fig. 5C, arrows). In Si+ plants, empty fungal hyphae were

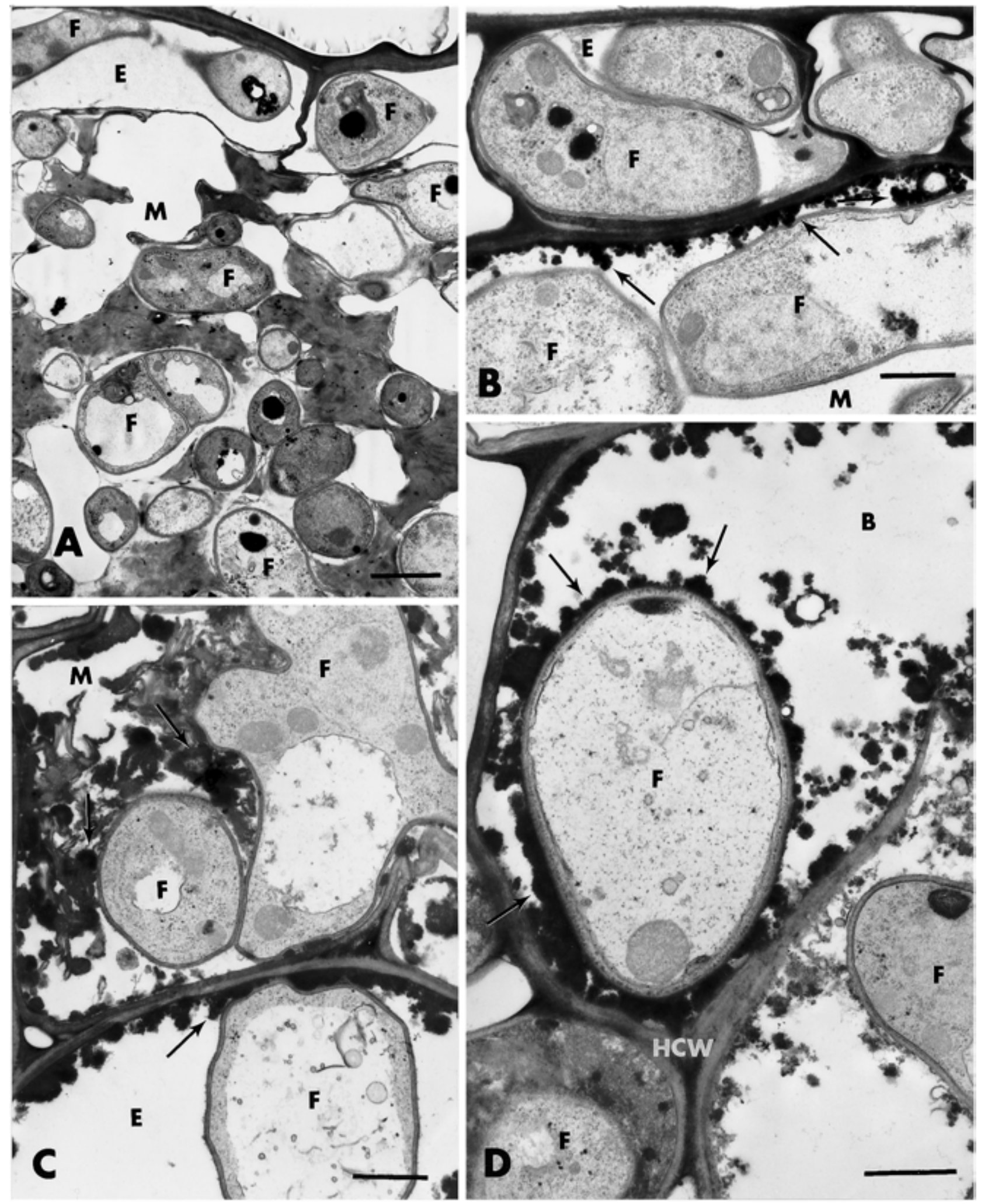

Fig. 6. Transmission electron micrographs of leaf samples collected from $\mathrm{Si}-$ and $\mathrm{Si}+$ rice plants $120 \mathrm{~h}$ after inoculation with Magnaporthe grisea. A, Ultrastructurally normal fungal hyphae colonize both the epidermis and the mesophyll. In the mesophyll, the fungal colonization causes extensive host cell damage $(\mathrm{Si}-)$. Bar $=2 \mu \mathrm{m}$. B, Epidermal cells are massively invaded by the fungus. A layer of amorphous material (arrows) coats the cell wall of a mesophyll cell but rarely interacts with fungal cell walls $(\mathrm{Si}-)$. Bar $=1 \mu \mathrm{m}$. C, Abundant amorphous material (arrows) interacts with fungal hyphae invading the epidermis and an underlying mesophyll cell $(\mathrm{Si}+)$. Bar $=1 \mu \mathrm{m}$. D, The amorphous material (arrows) regularly surrounds the cell wall of an invading hyphae in the bundle sheath extension (Si+). Bar $=1 \mu \mathrm{m}$. Fungal hyphae (F), epidermis (E), mesophyll (M), host cell wall (HCW), and bundle sheath extension (B). 
evenly surrounded by a dense layer of granular osmiophilic material partially occluding the epidermal cells (Fig. 5D, arrows), vascular bundle (Fig. 5E, arrowheads), and mesophyll cells (Fig. $5 \mathrm{~F}$, arrows).

By $120 \mathrm{~h}$ after inoculation, M. grisea had massively colonized the epidermis and the mesophyll in samples from $\mathrm{Si}-$ plants (Fig. 6A). This colonization caused severe host cell damage evidenced by the presence of much cellular debris and fragmented remnants of host cell walls around invading fungal hyphae in the mesophyll. Although granular amorphous material coated the cell walls of some mesophyll cells in samples from $\mathrm{Si}-$ plants, it rarely interacted with the fungus (Fig. 6B, arrows). In contrast, epidermal cells, mesophyll cells, and bundle sheath extension cells in samples from $\mathrm{Si}+$ plants were filled with the granular osmiophilic material that coated the fungal cell walls (Fig. 6C and D, arrows). Such a host response was markedly different in terms of extent and magnitude when compared with samples from $\mathrm{Si}-$ plants.

Cytochemical labeling. Incubation of ultrathin sections with the gold-complexed $\beta$-1,4-exoglucanase for the presence of cellulose resulted in a heavy and regular deposition of gold particles over the electron-dense host cell walls at 72 (Fig. 7A and B) and $96 \mathrm{~h}$ after inoculation (data not shown) with $M$. grisea in samples from both $\mathrm{Si}$ - and $\mathrm{Si}+$ plants. Gold particles were frequently associated with strands of disorganized wall fibrils often found in large amounts in samples from $\mathrm{Si}-$ plants (data not shown). As expected, the osmiophilic material surrounding fungal cell walls in samples from $\mathrm{Si}+$ plants at 72 and $96 \mathrm{~h}$ after inoculation with $M$. grisea was completely unlabeled (Fig. 7B, arrowheads, and $\mathrm{C}$ ). Application of the WGA/ovomucoid-gold complex for the presence of chitin to tissue sections of samples collected at $96 \mathrm{~h}$ after M. grisea inoculation, regardless of Si treatment, resulted in a regular deposition of gold particles strictly associated with the wall layers of the invading hyphae (Fig. 7D and E). No labeling could be detected over the osmiophilic material accumulating between the fungus and the host cell walls (Fig. 7E) in samples from $\mathrm{Si}+$ plants.

\section{DISCUSSION}

This study provides direct evidence that rice plants amended with Si respond to infection by $M$. grisea through a biochemical mechanism of cell defense. In line with the current trends toward unraveling the complex process by which $\mathrm{Si}$ operates to control rice blast $(17,21,43)$ and other diseases $(6,7,12,25)$, the present results not only bring support to the concept that Si increases rice resistance to infection by $M$. grisea $(8,32)$ but also provide the first ultrastructural evidence that production of phenolic-like compounds is correlated with a reduction of $M$. grisea development in rice plants amended with this element.

The possibility that the beneficial effect of $\mathrm{Si}$ in reducing the extent of $M$. grisea colonization may be associated with a biochemical response of the rice plant has never been reported. In previous investigations, the mechanism of Si-mediated rice blast resistance was associated with either the density of silicified cells in the epidermis $(15,17,38)$ or the formation of a cuticle-silica double layer upon Si deposition (43) which restricted penetration by $M$. grisea. Although several reports agree on the key role of phenolics in rice blast resistance $(22,27)$, positive correlation between $\mathrm{Si}$ application and an increase in the levels of fungitoxic compounds in infected cells are, thus far, lacking. Although the mechanical strength of epidermal cells conferred by Si polymerization can possibly impede $M$. grisea penetration, results of this study suggest that $\mathrm{Si}$ could also act as an effective modulator of rice defense responses, namely by influencing the synthesis of antifungal compounds after the penetration peg of $M$. grisea enters the epidermal cell.

Examination of $M$. grisea-infected leaf tissues obtained from $\mathrm{Si}-$ and $\mathrm{Si}+$ plants revealed marked differences in both the amount of fungal colonization and the number of viable fungal cells. Although the extent of fungal colonization might vary from one lesion to another, pathogen growth and development were systematically reduced in all examined samples obtained from $\mathrm{Si}+$ plants. Additionally, fungal cells suffered from serious alterations, a phenomenon not often observed in samples from $\mathrm{Si}-$ plants. Such differences in pathogen growth and development within rice tissues correlated well with the visual symptomatological observations, which clearly showed an evident reduction in lesion size on leaves from $\mathrm{Si}+$ plants compared with leaves from $\mathrm{Si}-$ plants.

A number of ultrastructural studies have demonstrated that induced resistance in monocots and dicots is often associated with the formation of papillae, cell wall lignification, wall appositions (callose deposition), and wall thickening $(2,30)$. Surprisingly, in this study, none of these structural host reactions were observed in either $\mathrm{Si}-$ or $\mathrm{Si}+$ rice plants. In contrast, $\mathrm{Si}+$ leaf cells were characterized by a massive accumulation of amorphous material that stained densely with toluidine blue and reacted positively to osmium tetroxide. The possibility that this amorphous material constitutes phenolic compounds appears realistic, considering not only its staining with toluidine blue and its texture and osmiophilic properties (31), but also the occurrence of marked fungal hyphae alterations. It is well known that the fungitoxic effect of most phenolics is attributed mainly to their interaction with lipids or phospholipids, causing an increase in fungal membrane permeability, leakage of cell contents, and cytoplasm aggregation (35, 42). An array of phenolic compounds such as chlorogenic, $p$ coumaric, ferulic, salicylic, cinnamic, and caffeic acids are known to occur in rice as preformed compounds $(22,40)$. Changes in the composition and levels of these pre- or postinfectional phenolic compounds may have been modulated by Si to enhance host resistance against infection by $M$. grisea. Ohata et al. (26) noted that a reduction in the degree of $M$. grisea invasion in the epidermal and mesophyll cells was linked to the content in flavonoids, ferulic acid, $p$-coumaric acid, $p$-hydroxybenzoic acid, and vanillic acid in these cells. Suzuki (39) provided a convincing argument that the production of phenolics at a low concentration within and around the infection sites delayed the necrotic response to infection by $M$. grisea. In fact, an important defense reaction of rice to infection by $M$. grisea is the production of phytoalexins (10). In addition to the preformed phenolics, the participation of phytoalexins such as sakuranetin or momilactones is an important factor associated with an increased resistance of rice plants to infection by $M$. grisea. The absence of structural reactions in rice tissues colonized by $M$. grisea clearly reinforces the involvement of phenolics, and phytoalexins, as a major host defense response against fungal infection. In this study, however, it does appear that the presence of Si has somehow positively affected the production of such compounds. Similar results have been reported in cucumber whereby plants amended with $\mathrm{Si}$ accumulated phenolic-like compounds in response to infection by Pythium ultimum and Sphaerotheca fuliginea $(7,25)$ in a manner quite similar to that described for phytoalexins in sorghum (34). Furthermore, Fawe et al. (12) reported that Siincreased resistance to $S$. fuliginea in cucumber was associated with the production of a new flavonol aglycone phytoalexin.

Support for a close association between accumulation of osmiophilic material, likely composed of phenolics, and host cell wall protection is illustrated by the differential pattern of cellulose labeling in host cells of samples from both $\mathrm{Si}-$ and $\mathrm{Si}+$ plants. The cytochemical results provide the first conclusive evidence that cellulose hydrolysis, one of the mechanisms involved in the degradation process exerted by $M$. grisea in rice leaf tissues, was apparently reduced in samples from $\mathrm{Si}+$ plants, even in colonized areas. This observation suggests that the impregnation of phenolic-like compounds in or beneath the rice cell walls may have contributed to the delay in colonization by $M$. grisea by reinforcing and protecting the cell walls from the deleterious action of 


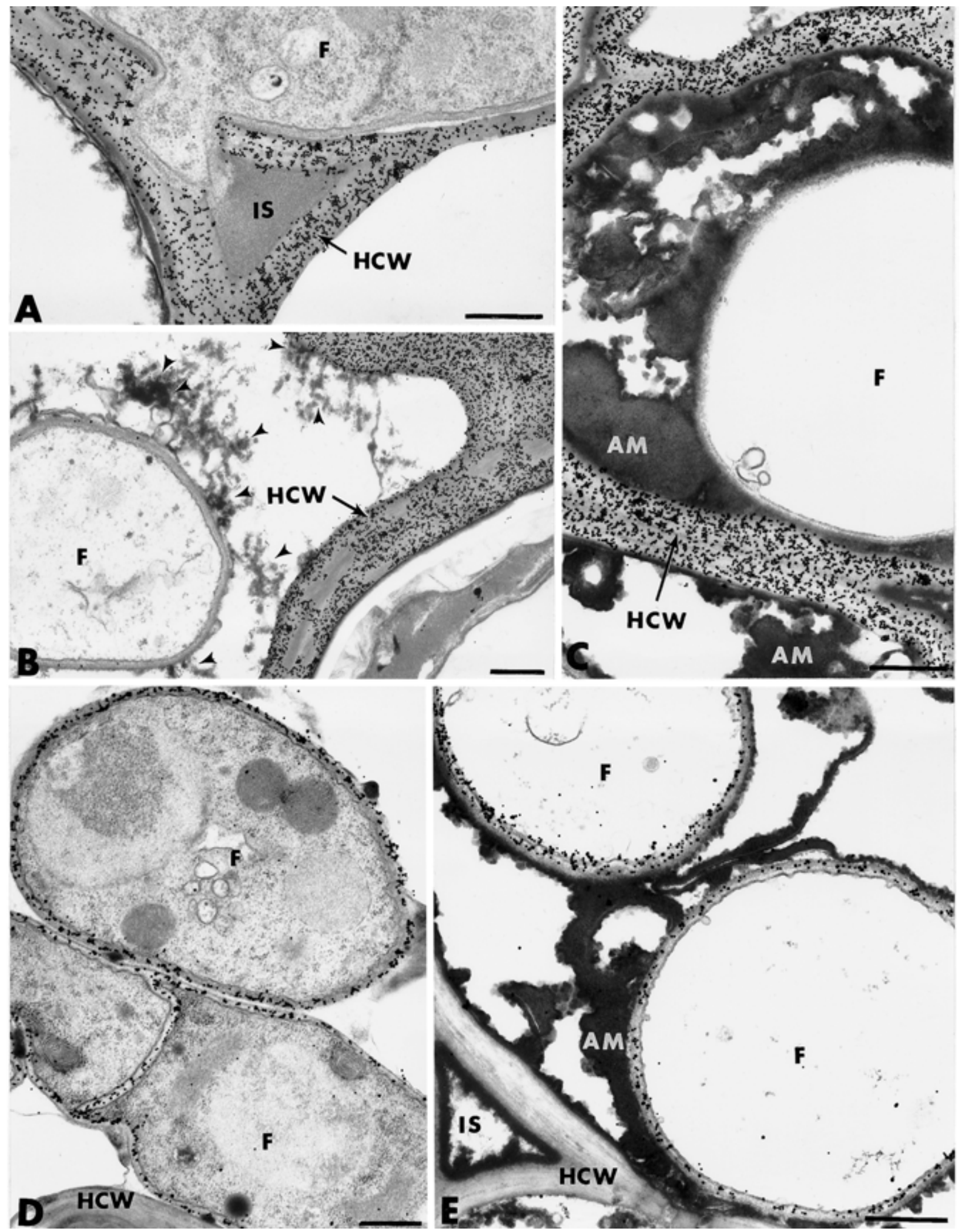

Fig. 7. Transmission electron micrographs of leaf samples collected from $\mathrm{Si}-$ and $\mathrm{Si}+$ rice plants inoculated with Magnaporthe grisea. Labeling of cellulose subunits with the gold-complexed $\beta-1,4-$ exoglucanase and chitin with wheat germ agglutinin (WGA)/ovomucoid-gold complex. A, A heavy and regular deposition of gold particles occurs over the electron-dense mesophyll cell walls, except in the areas of fungal penetration ( $72 \mathrm{~h}$ after inoculation; $\mathrm{Si}-$ ). B, Gold particles are regularly distributed over a mesophyll cell wall, whereas the osmiophilic material accumulating around the fungal cell wall is unlabeled (72 $\mathrm{h}$ after inoculation; Si+; arrowheads). C, A regular deposition of golden particles is seen over the cell wall of a mesophyll cell. Note the absence of gold particles over the amorphous material surrounding an empty fungal cell ( $96 \mathrm{~h}$ after inoculation; $\mathrm{Si}+$ ). $\mathbf{D}$, Gold particles are regularly distributed over the fungal cell walls invading a mesophyll cell. Note that the host cell wall is unlabeled ( $96 \mathrm{~h}$ after inoculation; $\mathrm{Si}-$ ). $\mathbf{E}$, An intense and even deposition of gold particles is evident over the fungal cell walls colonizing a mesophyll cell. Note that the osmiophilic material accumulating around both fungal hyphae and host cell walls is unlabeled. Fungal cell walls show slight sign of alteration without apparent chitin disorganization ( $96 \mathrm{~h}$ after inoculation; $\mathrm{Si}+)$. Bars $=0.5 \mu \mathrm{m}$. Fungal hyphae $(\mathrm{F})$, amorphous material (AM), intercellular space (IS), and host cell wall (HCW). 
both degrading enzymes and toxins produced by $M$. grisea, which together induce characteristic necrosis on the leaves.

Production of cell wall-degrading enzymes, such as cellulases and xylanases, by $M$. grisea is a very well-documented phenomenon $(37,41)$. In line with the known ability of this hemi-biotrophic fungus to secrete an array of lytic enzymes, one of the most conspicuous effects of fungal invasion in samples from $\mathrm{Si}$ - plants was the enzymatic degradation of host cell walls. The labeling patterns of cellulose provided evidence that $M$. grisea was able to produce cell wall-degrading enzymes that diffused to areas distant from the colonized tissue, causing considerable cell wall alterations and leading, eventually, to extensive tissue necrosis. The exact biological function played by the osmiophilic material, found either encrusted or underlying the rice cell walls in samples from $\mathrm{Si}+$ plants, is not clearly defined. However, one may speculate that the massive accumulation of this material might be associated with a chemical defense strategy elaborated by the host in order to prevent both the ingress and further colonization of $M$. grisea. Considering that $M$. grisea nutrition and successful invasion are prerequisites for lesion expansion (27), cell wall degradation is conceivably one of the most harmful events associated with the colonization process of this fungus $(37,41)$.

In an attempt to investigate whether chitinase, potentially triggered by $M$. grisea, plays a role in fungal cell wall disorganization, chitin was ultrastructurally localized using the WGA/ovomucoid-gold complex. The pattern of chitin localization over invading fungal hyphae in samples from $\mathrm{Si}-$ and $\mathrm{Si}+$ plants was similar in terms of uniformity and density at $96 \mathrm{~h}$ after inoculation with $M$. grisea. This observation does not exclude, however, the possibility that chitinases are produced in advanced stages of infection and might contribute to a partial or a complete disintegration of fungal cell walls. Plant chitinases are important enzymes in defense systems not only because they inhibit growth of $M$. grisea by causing dissolution of its cell walls (11), but they also are capable of releasing chitin oligomers that elicit other important cellular defense reactions. However, the fact that chitin is often embedded in a matrix of glucan fibers and complexed with some proteins and carbohydrates, make a few fungi sensitive to chitinases themselves (36). The observation that fungal cells, surrounded or trapped in the osmiophilic material, were reduced to empty shells at a time when a regular pattern of chitin labeling was observed over their cell walls clearly supports the hypotheses that phenolic-like compounds play an early and key role in the overall rice defense response to fungus infection.

Methods used to protect economically important crops such as rice against devastating pathogens like $M$. grisea are mainly focused on fungicides. New strategies being developed are based on the activation and enhancement of plant cellular defense reactions rather than the elimination of the pathogen. In line with this approach, results provided in this study support the conclusion that application of $\mathrm{Si}$ increases rice resistance against infection by $M$. grisea through the accumulation of phenolic-like compounds. This finding brings new insights into the complex role played by $\mathrm{Si}$ in the nature of rice blast resistance.

\section{ACKNOWLEDGMENTS}

This research was supported in part by the Florida Agricultural Experiment Station, research funds from Calcium Silicates Corporation, Inc. to L. E. Datnoff, a grant from RecMix, Inc. and the Natural Sciences and Engineering Research Council of Canada to R. R. Bélanger and J. M. Menzies, and the Canada Research Chairs Program to R. R. Belanger. We thank A. Goulet and C. Garand for their excellent technical assistance.

\section{LITERATURE CITED}

1. Benhamou, N. 1989. Preparation and applications of lectin-gold complexes. Pages 95-143 in: Colloidal Gold, Principles, Methods and Applications. Vol. 1. M. A. Hayat, ed. Academic Press, New York.
2. Benhamou, N. 1996. Elicitor-induced plant defense pathways. Trends Plant Sci. 1:233-240.

3. Benhamou, N., and Brodeur, J. 2000. Evidence for antibiosis and induced host defense reactions in the interaction between Verticillium lecanii and Penicillium digitatum, the causal agent of green mold. Phytopathology 90:932-943.

4. Benhamou, N., Chamberland, H., Ouellette, G. B., and Pauzé, F. J. 1987. Ultrastructural localization of $\beta-1,4-D-$ glucans in two pathogenic fungi in their host tissues by means of an exoglucanase-gold complex. Can. J. Microbiol. 33:405-417.

5. Bonman, J. M. 1992. Blast. Pages 14-16 in: Compendium of Rice Diseases. R. K. Webster and P. S. Gunnel, eds. The American Phytopathological Society, St. Paul, MN.

6. Chérif, M., Asselin, A., and Bélanger, R. R. 1994. Defense responses induced by soluble silicon in cucumber roots infected by Pythium spp. Phytopathology 84:236-242.

7. Chérif, M., Benhamou, N., Menzies, J. G., and Bélanger, R. R. 1992. Silicon induced resistance in cucumber plants against Pythium ultimum. Physiol. Mol. Plant Pathol. 41:411-425.

8. Datnoff, L. E., Deren, C. W., and Snyder, G. H. 1997. Silicon fertilization for disease management of rice in Florida. Crop Prot. 16:525531.

9. Datnoff, L. E., Seebold, K. W., and Correa-Victoria, F. J. 2001. Use of silicon for integrated disease management: Reducing fungicide applications and enhancing host plant resistance. Pages 171-184 in: Silicon in Agriculture. L. E. Datnoff, G. H. Snyder, and G. H. Korndörfer, eds. Elsevier Science, The Netherlands.

10. Dillon, V. M., Overton, J., Grayer, R. J., and Harborne, J. B. 1997. Differences in phytoalexin response among rice cultivars of different resistance to blast. Phytochemistry 44:599-603.

11. Du, L. C., and Wang, J. 1992. Activities and distribution of chitinases and $\beta-1,3$-glucanase in rice induced by Pyricularia oryzae. Acta Phytophysiol. Sinica 18:1-29.

12. Fawe, A., Abou-Zaid, M., Menzies, J. G., and Bélanger, R. R. 1998. Silicon-mediated accumulation of flavonoid phytoalexins in cucumber. Phytopathology 88:396-401.

13. Frens, G. 1973. Controlled nucleation for regulation of the particle size in monodisperse gold solutions. Nat. Phys. Sci. 24:20-22.

14. Hamer, J. E., Howard, R. J., Chumley, F. G., and Valent, B. 1988. A mechanism for surface attachment in spores of a plant pathogenic fungus. Science 239:288-290.

15. Hemmi, T., Abe, T., and Inoue, Y. 1941. Studies on the rice blast disease: Relation of the environment to the development of blast disease and races of the blast fungus. Noji Kairyo Shiryo 157:1-232.

16. Howard, R. J., and Ferrari, M. A. 1989. Role of melanin in appressorium formation. Exp. Mycol. 13:403-418.

17. Ito, S., and Hayashi, H. 1931. On the relation of silica supply to rice blast. J. Sapporo Soc. Agric. Sci. 103:460-461.

18. Ito, S., and Sakamoto, M. 1939. Studies on rice blast. Res. Hokkaido Univ. Bot. Lab. Fac. Agric. Rep. 1939-1943.

19. Jong, J. C., McCormack, B. J., Smirnoff, N., and Talbot, N. J. 1997. Generation of enormous turgor by accumulation of molar concentrations of glycerol in a plant pathogenic fungus. Nature 389:244-245.

20. Kawamura, E., and Ono, K. 1948. Study on the relation between the preinfection behavior of rice blast fungus, Pyricularia oryzae, and water droplets on rice plant leaves. J. Natl. Agric. Exp. Stn. 4:1-12.

21. Kim, S. G., Kim, K. W., Park, E. W., and Choi, D. 2002. Silicon-induced cell wall fortification of rice leaves: A possible cellular mechanism of enhanced host resistance to blast. Phytopathology 92:1095-1103.

22. Kuwatsuka, S., and Oshima, Y. 1962. Studies on polyphenols of rice plants, Part II. J. Agric. Chem. Soc. Jpn. 35:71-74.

23. Lee, Y. H., and Dean, R. A. 1994. Hydrophobicity of contact surface induces appressorium formation in Magnaporthe grisea. FEMS Microbiol. Lett. 115:71-75.

24. Matsuo, T., and Hoshikama, K. 1993. Science of the rice plant morphology. Food and Agriculture Policy Research Center, Tokyo.

25. Menzies, J. G., Ehret, D. L., Glass, A. D. M., and Samuels, A. L. 1991. The influence of silicon on cytological interactions between Sphaerotheca fuliginea and Cucumis sativus. Physiol. Mol. Plant Pathol. 39:403-414.

26. Ohata, K., Goto, K., and Kozaka, T. 1963. Observations on the reaction of rice cells to the infection of different races of Pyricularia oryzae. Ann. Phytopathol. Soc. Jpn. 28:34-30.

27. Ou, S. H. 1985. Rice Diseases. 2nd ed. Commonw. Agric. Bur., Kew, England.

28. Rodrigues, F. Á., Benhamou, N., Datnoff, L. E., Bélanger, R. R., Jones, J. B., and Korndörfer, G. H. 2002. Silicon induces a defense response to rice blast infection. Pages 29-30 in: Proc. 2nd Silicon Agric. Conf., Silicon Agric. Org. Comm./Jpn. Soc. Soil Sci. Plant Nutr., Tsuruoka, Yamagata, Japan.

29. Rodrigues, F. Á., Vale, F. X. R., Korndörfer, G. H., Datnoff, L. E., 
Oliveira, A. M., and Zambolim, L. 2003. Influence of silicon on sheath blight of rice in Brazil. Crop Prot. 22:23-29.

30. Sahashi, N., and Shishiyama, J. 1986. Increased papilla formation, a major factor of induced resistance in the barley Erysiphe graminis f. sp. hordei system. Can. J. Bot. 64:2172-2178.

31. Scalet, M., Crivellato, E., and Mallardi, F. 1989. Demonstration of phenolic compounds in plant tissues by an osmium-iodide postfixation procedure. Stain Technol. 64:273-290.

32. Seebold, K. W. 1998. The influence of silicon fertilization on the development and control of blast, caused by Magnaporthe grisea (Hebert) Barr, in upland rice. Ph.D. diss. University of Florida, Gainesville.

33. Seebold, K. W., Kucharek, T. A., Datnoff, L. E., Correa-Victoria, F. J., and Marchetti, M. A. 2001. The influence of silicon on components of resistance to blast in susceptible, partially resistant, and resistant cultivars of rice. Phytopathology 91:63-69.

34. Snyder, B. A., and Nicholson, R. L. 1990. Synthesis of phytoalexins in sorghum as a site-specific response to fungal ingress. Science 248:16371639.

35. Southerton, S. G., and Deverall, B. J. 1990. Histochemical and chemical evidence for lignin accumulation during the expression of resistance to leaf rust fungi in wheat. Physiol. Mol. Pathol. 36:483-494.

36. Stahl, E. A., and Bishop, J. G. 2000. Plant-pathogen arms races at the molecular level. Curr. Opin. Plant Biol. 3:299-304

37. Sumizu, K., Yoshikawa, M., and Tanaka, S. 1961. Studies of xylanase of Pyricularia oryzae. J. Biochem. 50:538-543.

38. Suzuki, H. 1940. On the relationship between rice susceptibility and penetration into host plants. Ngyo Oyobi Engei 10:1999-2010.

39. Suzuki, N. 1965. Nature of resistance to blast. Pages 277-301 in: The Rice Blast Disease. Johns Hopkins University Press, Baltimore, MD.

40. Varga, M. 1970. Correlation between the phenol content, polyphenolase and peroxidase activity and the growth of rice seedlings with particular respect to flooding conditions. Riso 19:353-360.

41. Walton, J. D. 1994. Deconstructing the cell wall. Plant Physiol. 104: 1113-1118.

42. Weete, E. R. 1980. Lipid Biochemistry of Fungi and Other Organisms. Plenum Press, New York.

43. Yoshida, S. S., Ohnishi, Y., and Kitagishi, K. 1962. Histochemistry of silicon in rice plant. III. The presence of cuticle-silica double layer in the epidermal tissue. Jpn. J. Soil Sci. Plant Nutr. 8:107-113.

44. Zeyen, R. J., Ahlstrand, G. G., and Carver, T. L. W. 1993. X-ray microanalysis of frozen-hydrated, freeze-dried, and critical point dried leaf specimens: Determination of soluble and insoluble chemical elements at Erysiphe graminis epidermal cell papilla sites in barley isolines containing $M l-o$ and $m l-o$ alleles. Can. J. Bot. 71:284-296. 